\title{
ІВАН ЗАБОЛОТНИЙ
}

ID ORCID https:/ 0000-0002-4876-2042 zabolotnyj@meta.ua професор

Сумський державний педагогічний університет імені А. С. Макаренка вул. Роменська 87, м. Суми

\section{ДИРИГЕНТСЬКО-ХОРОВА ПЕДАГОГІКА ЯК МИСТЕЦЬКО-ОСВІТНІЙ ФЕНОМЕН}

\begin{abstract}
Розглянуто теоретичні основи диригентсько-хорової педагогіки як мистецько-освітнього феномена. Вказано, шзо актуальність проблеми диригентсько-хорової педагогіки посилюється у зв'язку з урахуванням специфіки професійно-педагогічної діяльності вчителя музики, а також в практичній роботі, в якій важливе місце займає диригентсько-хорова підготовка, щзо впливає на духовний світ вчителів майбутніх музики і учнів. Розглянуто наукові прачі вітчизняних дослідників сучасності 3 питань означеного феномена, в яких розкрито роль диригентсько-хорової педагогіки. Висвітлено особливості збереження і відродження традицій диригентсько-хорової педагогіки. Акиентовано увагу на важливості використання сучасних наукових досліджень в иій галузі. Аналіз сучасних досліджень означеного феномена, дає підстави стверджувати про внесення коректив до структурнокатегоріального апарату, які забезпечують успішну практичну реалізацію змісту навчально-виховного процесу. Наголошено, щзо формування професійних компетентностей майбутнього вчителя музики у навчальному процесі з фахової дисцииліни «Хорове диригування» має проходити в індивідуальних та групових формах навчання. Окреслено певні завдання диригентсько-хорової педагогіки, ії змістовного, структурного та методологічного рівнів майбутнього вчителя музики. Згідно з завданням диригентсько-хорової педагогіки до структури навчального прочесу визначено $і$ охарактеризовано педагогічні функиії. Наголошено на потребі використання у навчальному прочесі з дисцииліни «Хорове диригування» нових методів та прийомів, які передбачають засвоєння професійних знань, навичок та вмінь і перетворюються в неповторну духовно-творчу індивідуальність майбутнього фахівия, стають головними константами його діяльності.
\end{abstract}

Ключові слова: диригентсько-хорова педагогіка, вчитель музики, педагогічні функиї, навчальний проиес.

ИВАН ЗАБОЛОТНЫЙ

профессор

Сумский государственный педагогический университет имени А. С. Макаренка ул. Роменская, 87, г. Сумы

\section{ДИРИЖЕРСКО-ХОРОВАЯ ПЕДАГОГИКА КАК ХУДОЖЕСТЕННО- ОБРАЗОВАТЕЛЬНЫЙ ФЕНОМЕН}

Рассмотрены теоретические основы дирижерско-хоровой педагогики как художественнообразовательного феномена. Указано, что актуальность проблемы дирижерско-хоровой педагогики усиливается в связи с учетом специфики профессионально-педагогической деятельности учителя музыки, а также в практической работе, в которой важное место занимает дирижерско-хоровое подготовка, влияет на духовный мир учителей будущих музыки и учеников. Рассмотрены научные труды отечественных исследователей современности по вопросам обозначенного феномена, в которых раскрыта роль дирижерско-хоровой педагогики. Освещены особенности сохранения и возрождения традиций дирижерско-хоровой педагогики. Акцентировано внимание на важности использования современных научных исследований в этой области. Анализ современных исследований указанного феномена, дает основания утверждать о внесении корректив в структурно-категориальньй аппарат, который обеспечивает успешную практическую реализацию содержания учебно-воспитательного прочесса. Отмечено, что формирование профессиональных компетенций будущего учителя музыки в учебном процессе по профессиональной дисциплине «Хоровое дирижирование» должен проходить в индивидуальных и групповых формах обучения. Определены некоторые задачи дирижерско-хоровой педагогики, ее содержательного, структурного и методологического уровней будущего учителя музыки. 
Согласно заданию дирижерско-хоровой педагогики в структуру учебного процесса определень и охарактеризовань педагогические функиии. Отмечена необходимость использования в учебном прочессе по дисциплине «Хоровое дирижирование» новых методов и приемов, которые предусматривают усвоение профессиональных знаний, навыков и умений и превращаются в неповторимую духовно-творческую индивидуальность будущего специалиста, становятся главными константами его деятельности.

Ключевые слова: дирижерско-хоровое педагогика, учитель музыки, педагогические функции, учебный процесс.

\title{
IVAN ZABOLOTNYI
}

\author{
Professor
}

A. S. Makarenko Sumy State Pedagogical University

87 Romenska Str., Sumy

\section{CONDUCTING CHORAL PEDAGOGY AS AN ARTISTIC AND EDUCATIONAL PHENOMENON}

The theoretical basis of conducting choral pedagogy as an artistic and educational phenomenon have been considered in the article. It has been pointed out that the urgency of the problem of conducting choral pedagogy is exacerbated in connection with the specificity of the music teacher's professional and pedagogical activity, as well as in the practical work in which the conducting choral training, which influences the spiritual world of future music teachers and students, occupies an important place. The scientific works of national researchers of the present time on the issues of the identified phenomenon are considered, in which the role of conducting choral pedagogy as an art-educational phenomenon is revealed. The features of preserving and reviving the traditions of conducting choral pedagogy as an artistic and educational phenomenon are highlighted. Attention is paid to the importance of using modern scientific research in the field of conducting choral pedagogy. It is stated that the educational process of the future music teacher of conducting and choral disciplines influences the future specialist's spiritual outlook. The analysis of the current scientific research of the phenomenon gives grounds to argue for the introduction of adjustments to the structural and categorical apparatus, which make possible the successful practical implementation of the content of the educational process. The theor etical and practical importance of conducting and choral disciplines is noted. The prospects of formation of conducting choral knowledge and skills in the educational process of future music teachers training are especially outlined. It is emphasized that professional competencies formation of the future music teacher in the educational process in the professional discipline "Choral Conducting" should be carried out in individual and group forms of education, which is determined by the basic principles and traditions of the national music-pedagogical school. Some tasks of conducting choral pedagogy, its content, structural and methodological levels of the future music teacher are outlined. According to the tasks of conducting choral pedagogy and the educational process structure pedagogical functions are defined and characterized. The necessity of using the new methods and techniques in the process of teaching "Choral Conducting" is emphasized. This course involves the acquisition of professional knowledge, skills and abilities that transform into the unique spiritual and creative personality of the future specialist and become the main constants of his or her activity.

Keywords: conducting choral pedagogy, music teacher, pedagogical functions, educational process.

Процес модернізації освіти нашого суспільства ставлять нові вимоги до якості і рівня підготовки майбутніх фахівців. Інтеграція нових підходів у професійній підготовці майбутніх фахівців дає можливість забезпечити їх спроможність у освітньому просторі, де одним із головних критеріїв їхня професійна компетентність. Зважаючи на пріоритетність мистецької освіти у навчальному закладі, формування професійної компетентності студентів не може відбуватися без належної диригентсько-хорової педагогіки. Актуальність проблеми посилюється у зв'язку з урахуванням специфіки професійно-педагогічної діяльності вчителя музики, в практичній роботі якого важливе місце займає диригентсько-хорова підготовка, що впливає на духовний світ учнів. При цьому важливим є те, що «в процесі формування у вчителя готовності до виконання завдань музично-естетичного виховання учнів музично-педагогічна діяльність є початковою ланкою у всьому, що має стосунок до його професії» [8, с. 5]. Останнє постає як «процес складний та довготривалий, в його основі повинна бути закладена послідовна система виховання майбутнього педагога, яка спирається на загальнолюдські цінності, досвід світової педагогічної практики 3 урахуванням особливостей розвитку сучасного суспільства» [6, с. 242]. Тому важливим аспектом у вдосконаленні процесу професійної підготовки вчителів музики є поглиблення досліджень, присвячених актуальним питанням щодо формування диригентсько-хорових знань, навичок та вмінь. 
Мистецько-освітній феномен належить до практичного засвоєння студентом знань про хорове мистецтво і культуру як духовну сферу, що в подальшому впливає на адаптацію іiі в культурному просторі та дає можливість стати суб'єктом його творення. Як зауважив Ю. Богуцький, «характер та міра сприйняття людиною того чи іншого твору мистецтва $€$ похідними від іiі здатності реагувати на нього не лише як на готовий результат творчої діяльності, але й як результат процесу творення» [2, с. 159].

Метою статті: проаналізувати сучасні дослідження, присвячені диригентсько-хоровій педагогіці як мистецько-освітнього феномена, розкрити значення диригентсько-хорової педагогіки у музичної освіті майбутніх фахівців, визначити й охарактеризувати педагогічні функції у навчальному процесі з дисципліни «Хорове диригування».

Зацікавленість професійного вчителя музики звертає увагу дослідників і практиків на використання сучасних наукових джерел у навчально-виховному процесі з дисципліни «Хорове диригування», узагальнення наукових праць 3 підготовки майбутніх учителів музики до фахового самовдосконалення при вивченні диригентсько-хорових дисциплін (А. Авдієвський, О. Бенч-Шокало, М. Канерштейн, Т. Мартинюк, В. Рожка, Є. Савчук та ін.), розробки методик диригентсько-хорового навчання майбутніх фахівців (А. Болгарський, Д. Бондаренко, П. Ковалик, А. Козир, О. Коренюк, А. Лащенко, А. Мартинюк, Т. Смирнова, та ін.) Аналіз досліджень підтверджує, що диригентсько-хорова педагогіка поширює художній світогляд та музично-хорову виконавську естетику у майбутніх вчителів музики. Разом 3 тим питання диригентсько-хорової педагогіки у навчальному процесі підготовки майбутніх вчителів музики має уточнення в науковій та навчально-методичній літературі.

В сучасних умовах проблема диригентсько-хорової педагогіки полягає в тому, щоб допомогти майбутньому вчителю музики засвоїти механізм практичної реалізації змісту навчального процесу з урахуванням інтересів та музичних здібностей учнів, особистої творчої індивідуальності. Т. Смирнова у зв’язку 3 цим стверджує: «Значною мірою соціальнопсихологічний клімат колективу визначають неформальні контакти на репетиціях, концертах i поза ними, співробітництво і взаємодопомога співаків та диригента хору. На соціальнопсихологічний клімат колективу значно впливає стиль керівництва, який переважно застосовує диригент хору» $[10$, с. 96$]$.

Важливе місце у підготовці майбутнього вчителя посідає самоствердження його як освіченої, духовно багатої, інтелектуально-моральної, ініціативної, відповідальної особистості, здатної розвивати інноваційні процеси та ідеї, необхідність серйозного перегляду їі змісту. Нові методи та прийоми диригентсько-хорової педагогіки повинні зайняти лідируючу позицію у навчальному процесі.

Загальновідомо, що важливим аспектом диригентсько-хорової педагогіки як мистецькоосвітнього феномена $\epsilon$ формування духовного світогляду студентів навчальних закладів, де здійснюють підготовку майбутніх фахівців за спеціальними педагогічними дисциплінами, а саме: «Хорове диригування», «Хорознавство», «Хоровий клас» та ін. Саме духовність набуває інтегрального багатомірного характеру, передбачає органічну єдність інтелектуальних, моральних, естетичних і професійних компонентів і традицій. Гуманістичні принципи навчання і виховання дають підставу розглядати майбутнього фахівця як неповторну цілісну особистість, котра здатна робити свідомий та відповідальний вибір у різноманітних життєвих ситуаціях. Як засвідчує сучасна хорова практика, новітні творчі пошуки композиторів у галузі композиторської техніки і засобів їх відтворення народжуються під впливом традиційного виконавства, внаслідок серйозного його переосмислення. Так, хорові твори, зроблені видатним диригентом А. Авдієвським на вірші українських поетів, становлять цікаву і органічну частку сучасного композиторського доробку, до яких звертаються професійні і аматорські колективи, оскільки відчувають в них народження національних музичних традицій, засади художнього мислення. «Моя практика диригента безумовно впливає на творчий процесс..., збереження відповідних особливостей національних традицій в співі... Українська народна пісня являє собою таке національне багатство, довершений мистецький рівень..., щоб відтоворити багатство пісенного поля, зберігаючи його колорит, національні особливості...» $[1$, с. 4$]$ - писав А. Авдієвський.

Професійна майстерність майбутніх вчителів музики у процесі вивчення диригентськохорових дисциплін базується на всебічному розвитку музичних здібностей. Складовими поняття «музичні здібності» $є$ : музичний слух, бездоганне почуття ритму, хороші голосові дані, музична пам'ять, слухове сприйняття, творча уява та спостережливість, здібність до 
інтерпретації. Це дає змогу свідомо підвищити відповідальність як за розвиток творчої особистості, що постійно вдосконалюється, так і музичної освіти загалом. Стосовно цього, А.Козир зазначає, що «з боку вчителя передбачає його певну активність, тобто: розробку засобів навіювання для впливу на хористів, з метою створення яскравого художньо-музичного образу виконуваного твору; підготовку для створення деякого, бажано позитивного, враження про себе в шкільному хоровому колективі, самопрезентування в процесі педагогічної взаємодії» [4, с. 100].

Теоретичним підгрунтям для розробки нових навчальних курсів в галузі диригентськохорової педагогіки $є$ наукові дослідження В. Рожка. На думку вченого, основними складовими історичного аспекту диригентсько-хорового педагогіки і навчальної дисципліни «Хорове диригування» $€$ розвиток теорії і методики диригування; еволюція диригентського виконавства; становлення і функціонування системи диригентсько-хорової освіти [9, с. 63-74].

Важливий аспект щодо історичного розвитку диригентсько-хорової педагогіки висловлює А. Лащенко. Дослідник сучасного хорового мистецтва зазначає, що навчальна дисципліна «Хорове диригування» має охоплювати глобальні історичні, теоретичні й методичні проблеми диригентсько-хорової педагогіки, інтегрувати відомості з музичної психології, акустики, літературознавства [5, с. 18-31].

Дисципліни диригентсько-хорового циклу є фундаментальними в підготовці учителя музики у використанні певних завдань, а саме: 1) вплив на формування знань, вмінь та навичок, які забезпечують можливість реалізації професійно педагогічної діяльності; 2) підготовка майбутніх учителів музики до важливого виду дитячої творчості (наприклад, співоча діяльність, що є особливим менталітетом для України) та найбільш поширеною в умовах загальноосвітньої школи; 3) формування сприятливих умов для підготовки фахівців до роботи 3 хоровим колективом.

Ці завдання вирішуються взаємними зусиллями при викладанні всіх дисциплін диригентсько-хорового циклу, котрі взаємодіють 3 такими, як методика постановки голосу, методика викладання диригування, методика роботи зі шкільним хоровим колективом, методика музичного виховання.

Доречно відзначити, що навчальна дисципліна «Хорове диригування» $є$ основою у навчальному процесі підготовки майбутніх вчителів музики на мистецьких факультетах, предметом вивчення якої є теоретичне і практичне засвоєння комплексу питань:

- оволодіння навичками та вміннями техніки диригування;

- розвиток вокально-хорового слуху;

- методика диригентсько-хорової роботи над інтонацією, звукоутворенням, дикцією тощо;

- засвоєння методики репетиційного процесу;

- оволодіння навичками психологічного впливу на колектив та ін.

Доведено, що формування професійних компетентностей майбутнього вчителя музичного мистецтва у навчальному процесі з фахової дисципліни «Хорове диригування» має здійснюватись у формі практичних індивідуальних і групових занять, що зумовлено основними принципами і традиціями вітчизняної музично-педагогічної школи.

Важливу роль на першому етапі навчання в галузі диригентської педагогіки, як зауважують відомі педагоги-диригенти, $\epsilon$ набування навичок 3 техніки диригування: відпрацювання пластичних, ціленаправлених диригентських жестів на основі координації рухів плеча, передпліччя, кисті, розвитку міміки лиця; вміти оптимально координувати емоціональні і раціональні фактори у розкритті художніх образів та розвинути асоціації як необхідний компонент для художнього виконання твору та встановлення контакту з уявним хором. Стосовно цього М. Канерштейн вказував, що засоби та прийоми, які входять у поняття «техніка диригування», взаємопов'язані, перебувають у певній єдності на грунті глибокого розуміння музичного тексту [3, с. 68]. Метою цього періоду $є$ особистісна готовність диригента до репетицій з хоровим колективом.

У навчальному процесі з дисципліни «Хорове диригування» педагогу необхідно розкрити творчу індивідуальність студента. Так, професор Харківського державного університету мистецтв імені І. П. Котляревського А. Мірошникова вказує на важливість індивідуального підходу до розвитку кожного студента, що вимагає, на іiі думку, врахування особистісних якостей майбутніх виконавців і педагогів, уникнення стандартизації в процесі диригентськохорової освіти [7, с. 7]. 3 метою розвитку художнього мислення майбутніх фахівців педагог 
залишає можливість для індивідуального трактування музичних творів, для придбання виконавських якостей, які необхідні диригентові для ефективного впливу на хоровий колектив, що викликають яскраві емоційні переживання у виконавців, збагачують їх духовний світогляд.

Узагальнюючи вищесказане, у навчальному процесі диригентсько-хорової педагогіки можемо окреслити певні завдання:

1) поширення знань, вмінь та навичок в галузі диригентсько-хорової педагогіки;

2) засвоєння стильових напрямків світового та вітчизняного диригентсько-хорового мистецтва;

3) виявлення специфічних особливостей індивідуальних композиторських стилів в щодо взаємодії традицій і новаторства;

4) збагачення досвіду сприйняття i поглиблення розуміння процесів музичного мистецтва.

Спираючись на систему загальних функцій мистецтва і функцій художньо-музичного навчання, вважаємо, що функції означеного феномена полягають у забезпеченні відповідності конкретній меті навчального процесу:

- пізнавальна функція передбачає диригентсько-хорову педагогіку в історичному аспекті. Диригентсько-хорове мистецтво $є$ засобом навчання, навичок мислення, узагальнення системи поглядів;

- компенсаторна функція розглядається нами як мистецтво релаксації, що дає змогу людині в процесі сприймання художнього твору пережити ті почуття, яких вона була позбавлена в реальному житті, та вижити у найважчих умовах. За допомогою диригентськохорового мистецтва людина може звільнитися від негативного стану і прийти від стресових переживань до своєрідного вивільнення й гармонії самопочуття. Саме тому диригентськохорове мистецтво здатне виконувати релаксаційну місію;

• інноваційно-креативну функцію пов'язуємо з творчим перетворенням дійсності. Така функція відповідного просторового утворення виявляється у безпосередньому створенні нових знань, технологій і техніки та їхньому поширенні. Сучасний педагог повинен знати тенденції інформатизації освіти: 1) розкрити психолого-педагогічні умови використання інформаційнокомунікаційних технологій у роботі зі студентами; 2) вміти користуватися новими освітніми технологіями, застосовувати педагогічні можливості інформаційно-комунікаційних технологій у своїй професійній діяльності; 3 ) сприяти формуванню основ інформатичних компетентностей та інформаційної етики у майбутніх вчителів музики;

- сугестивна функція полягає у емоційному впливі диригентсько-хорового мистецтва. Емоційний вплив означеного феномена діє на почуття особистості, вдосконалюючи чи руйнуючи іï;

- гедоністична функція передбачає сферу свободи й майстерності диригентсько-хорового мистецтва, які несуть естетичну насолоду. Джерелом естетичної насолоди $є$ художня форма, яка перебуває у гармонійній єдності зі змістом;

- виконавська функція диригентсько-хорового мистецтва здійснюється на засадах володіння фахівця професійними навичками, уміннями інтерпретувати та відтворювати художньо-образний зміст твору в процесі донесення його до слухача.

Таким чином, проведений огляд сучасних досліджень диригентсько-хорової педагогіки дає підстави стверджувати, що вони повинні використовуватися у навчальному процесі 3 дисципліни «Хорове диригування», дають змогу окреслити певні завдання цій педагогіки та виокремити педагогічні функції до навчального процесу з означеної дисципліни.

Перспективою подальшого розгортання досліджуваної проблеми $\epsilon$ визначення інноваційних методів і прийомів у викладанні дисципліни «Хорове диригування».

\section{ЛІТЕРАТУРА}

1. Авдієвський А. У руслі національно-культурних традицій /А. Авдієвський // Мистецтво і освіта. 2001. - № 2. - C. 24-25.

2. Богуцький Ю. Самоорганізація культури: онтологія, динаміка, перспективи: монографія / Ю. Богуцький. - К.: Веселка, 2008. - 199 с.

3. Канерштейн М. Вопросы дирижирования / М. М. Канерштейн. - М.: Музыка, 1972. -255 с.

4. Козир А. Професійна майстерність учителів музики: теорія і практика формування в системі багаторівневої освіти: монографія /А.В.Козир. - К.: НПУ імені М. П. Драгоманова, 2008. - 378 с. 
5. Лащенко А. Українське хорове мистецтво XX ст. / А. Лащенко // Науковий вісник Національної музичної академії України імені П. І. Чайковського. Вип. 14: Музичне виконавство. Кн. 6. - К., 1999. - C. 18-31.

6. Микитюк І. Роль вчителя як суб’єкта педагогічної культури / I. А. Микитюк // Педагогіка вищої та середньої школи: зб. наук. праць / гол. ред. проф. В. К. Буряк. - Кривий Ріг: КДПУ, 2009. - Вип. 26: Мистецька освіта в Україні (теорія, методи, технологіï). - С. 242-245.

7. Мирошникова А. Воспитание профессиональных качеств дирижера-хормейстера в классе хорового дирижирования / А. Мирошникова. - К., 1993. - 16 с.

8. 8. Освіта: Україна XXI століття. Державна національна програма: Збірник нормативно-правових актів 3 питань загальної середньої освіти. - К., 2010. - Т. 1. - С. 3-5.

9. . Рожок В. Диригентське мистецтво України / В. Рожок // Музика і сучасність: Монографічні дослідження. Науково-популярні, критичні та публіцистичні твори. - К.: Книга пам'яті України, 2003. - C. 63-74.

10. . Смирнова Т. Вища диригентсько-хорова освіта в Україні: минуле та сучасність: монографія / Т. А. Смирнова. - Харків: Константа, 2002. - 256 с.

\section{REFERENCES}

1. Avdiyevsky A. U rusli natsionalno-kulturnykh tradytsii. [In line with national and cultural traditions]. Arts and Education, 2001, vol. 2, pp. 24-25.

2. Bogutskyi Y. Samoorhanizatsia kultury: ontolohia, dynamika, perspektyvy. [Self-organization of culture. Ontology, dynamics, perspectives]. Kyiv, Veselka, 2008, 199 p.

3. Kanerstein M. Voprosy dyryzhyrovania [Questions of conducting]. Moscow, Music, 1972, 255 p.

4. Kozyr A. Profesiina maisternist uchyteliv muzyky: teoria i praktyka formuvannia $v$ systemi bahatorivnevoi osvity. [Professional skill of music teachers: theory and practice of formation in the system of multilevel education]. NPU imeni M. Drahomanova. Kyiv, 2008, 378 p.

5. Lashchenko A. Ukrainske khorove mystetstvo XX st. [Ukrainian choral art of the XX century]. Naukovyi visnyk Natsionalnoi muzychnoi akademii Ukrainy imeni P. I. Chaikovskoho. Kyiv, 1999, vol. 14, pp. 1831. (in Ukraine).

6. Mykytiuk I. Rol vchytelia yak subiekta pedahohichnoi kulturyю [The role of the teacher as a subject of pedagogical culture]. Pedahohika vyshchoi ta serednoi shkoly. Kryvyi Rih, KSPU, 2009, vol. 26, pp. 242245.

7. Miroshnikova A. Vospitanie professionalnykh kachestv dirizhera-khormeystera v klasse khorovoho dirizhirovannia. [Upbringing of professional qualities of a choir conductor in the class of choral conducting]. Kyiv, 1993, 16 p.

8. Osvita. Ukraina XXI stolittia. Derzhavna natsionalna prohrama [Education. Ukraine of the XXI century. State National Program]. Zbirnyk normatyvno-pravovykh aktiv z pytan zahalnoi serednoi osvity. Kyiv, 2010, vol. 1, pp. 3-5. (in Ukraine).

9. Rozhok V. Dyryhentske mystetstvo Ukrainy. Muzyka i suchasnist: Monohrafichni doslidzhennia. Naukovo-populiarni, krytychni ta publitsystychni tvory. [Conducting Art of Ukraine]. Kyiv, Knyha Pamiati Ukrainy, 2003, pp. $63-74$.

10. Smirnova T. Vyshcha dyryhentsko-khorova osvita v Ukraini: mynule ta suchasnist [Higher conductorchoir education in Ukraine]. Kharkiv, Constant, 2002. 256 p. 